JAKUB URBANIK

Uniwersytet Warszawski

\title{
FORMALNOŚĆ ROZWODU W RZYMSKIM PRAWIE KLASYCZNYM: D. 24,2,9 I AUGUSTOWSKIE DIVORTIIS MODUM IMPONERE
}

I. WPROWADZENIE: FORMALNOŚĆ ROZWODU A AFFECTIO MARITALIS JAKO FUNDAMENT RZYMSKIEGO MAŁŻEŃSTWA

Jedną z najżywiej dyskutowanych kwestii w rzymskim prawie małżeńskim jest problem formalności rozwodowych. Powód jest oczywisty: ustalenie, czy rozwód rzymski wymagał jakichkolwiek procedur przekłada się wprost na naszą wizję małżeństwa rzymskiego i akceptację - lub nie - wizji Edoardo Volterry o powstawaniu tegoż. Czy zatem małżeństwo było - tak jak postulował ten wielki włoski romanista - związkiem wolnym, trwającym tak długo, jak trwała affectio maritalis każdego z małżonków, czy też raczej małżeństwo rzymskie swoją konstrukcją przypominało doskonale znany nam stan prawny: zgoda początkowa je formuje, a trwa dopóty, dopóki nie zostanie wyrażona wola przeciwna, w mniej lub bardziej sformalizowanym akcie rozwodu. Na początek należy wyjaśnić, jak rozumiem pojęcie ,formalności“, czy też „przesłanek rozwodu“. Zakres znaczeniowy tych terminów z pewnością nie odpowiada przepisom współczesnego prawa cywilnego czy rodzinnego i opiekuńczego ${ }^{1}$. Przedmiotem moich ba-

${ }^{1}$ Exempli gratia por. nasz Kodeks rodzinny i opiekuńczy, art. 56, La legge dal 1 
dań jest ustalenie, czy rozwód w prawie rzymskim wywoływał zwykły fakt, sygnalizujący ustanie woli pozostawania w małżeństwie u choćby jednego z małżonków, czy też musiały zajść jakieś ściśle określone okoliczności, w których małżonkowie (i tylko oni) ${ }^{2}$, mogli wyrazić wolę zerwania istniejącego związku; czyli, innymi słowy, skuteczny rozwód wymagał jakiejś ściśle określonej procedury. Nie ulega wątpliwości, że dla czasów późniejszych ta hipoteza łatwo się weryfikuje: dość przypomnieć regulację z 10 lipca 439 wprowadzającą obowiązek sporządzenia listu rozwodowego jako jedynie dopuszczalnego sposobu dokonania rozwodu (NTh. 12 De repudiis Impp. Theod(osius) et Valent(inianus) AA. Florentio P(raefecto) P(raetorio). Consensu licita matrimonia posse contrahi, contracta nisi misso repudio dissolvi praecepimus - brak niestety jednoznacznych poświadczeń, czy reguła ta znalazła powszechne zastosowanie w praktyce). Kwestią otwartą

dicembre 1970 n. 898: Disciplina dei casi di scioglimento del matrimonio: artt. 1 i 3 w odniesieniu do art. 151 (1942) czy $B G B \S \S$ 1565-1568.

${ }^{2}$ To zastrzeżenie wyłącza $\mathrm{z}$ przedmiotu moich badań problem czynników zewnętrznych w stosunku do woli samych małżonków, które mogłby wpływać na rozwód. Mam tu przede wszystkim na myśli możliwy wpływ (i jego formę) osób trzecich na rozwód, zwłaszcza ojca na rozerwanie małżeństwa dzieci (na ten temat pisałem obszernie w D. 24,2,4: ... 'pater tamen eius nuntium mittere posse': l'influsso della volontà del padre sul divorzio dei sottoposti, [w:] T. DERDA, J. URBANIK, M. Węcowski, 'Evęrerías xá@ı. Studies Presented to Benedetto Bravo and Ewa Wipszycka by Their Disciples, Warsaw 2002, s. 293-336), czy też patrona, który zgodnie z ustawami Augusta musiał zgodzić się na rozwód żony - byłej niewolnicy wyzwolonej - w celu zamążpójścia za niego (na ten temat por. niżej: s. 100-102). Nie będą też przedmiotem moich zainteresowań w tym miejscu ogólne ograniczenia rozwodu w prawie publicznym, od tak zwanych ustaw Romulusa - na temat dopuszczalności rozwodu we wczesnym prawie rzymskim porównaj ostatnio A. TARWACKA, Rozwód Carviliusa Rugi. Czy naprawde pierwszy?, «CPH» 54.1 (2002), s. 301-308, oraz mój tekst: 'Res tuas habeto': la funzione delle ,parole approvate” nel divorzio, [w:] Dire le droit: normes, juges, jurisconsultes, ed. B. Anagnostou Canas, Paris 2006, s. 8798 - po ograniczenia w prawie cesarskim od Konstantyna począwszy, a na Justynianie skończywszy, por. mój artykuł: Konstantyńskie ograniczenie rozwodów: wolność matżeństw przebita szpilka do włosów, «Studia Iuridica» 45 (2006), s. 255-268. Ogólnie o przesłankach rozwodu por., m. in., P. Bonfante, Corso di diritto romano, I: Il diritto di famiglia ${ }^{2}$, Milano 1963, 334-339 [= 1a ed. 245-249]. 
w doktrynie pozostaje jednak fakt istnienia usankcjonowanych sposobów dokonania rozwodu w czasach klasycznych i przedklasycznych ${ }^{3}$.

By nie nużyć nadmiernie Czytelnika, pozwalam sobie opuścić rozważania nad możliwymi procedurami rozwodowymi istniejącymi w czasach archaicznych i przedklasycznych. Przypomnę jedynie konkluzję mych badań ${ }^{4}$ : nie da się wykluczyć, że w czasach archaicznych zarówno dla powstania, jak i do zerwania małżeństwa potrzebny był i w Rzymie magiczno-sakralny rytuał. Rzeczywistość stworzona dzięki performatywnej funkcji sakralnego aktu zawarcia małżeństwa, potrzebowała contrarius actus, by zostać rozerwana. Być może istniejące w źródłach ${ }^{5}$ informacje na temat ,uznanej“ (por. Gai. D. 24,2,2,1) for-

${ }^{3} \mathrm{O}$ nadal trwającej w doktrynie kontrowersji przekonują najdobitniej publikowane niedawno prace Riccardo Astolfiego, zwłaszcza Il matrimonio nel diritto romano classico, Padova 2006, passim, gdzie tezy Volterry o affectio maritalis jako fundamencie małżeństwa rzymskiego podlegają daleko idącym zmianom, a źródła, które staną w centrum moich rozważań w tym artykule, interpretowane są na sposób zgoła odmienny od volterriańskiego.

${ }^{4}$ Por. 'Res tuas habeto', cit. passim, oraz wcześniejszą literaturę dotyczącą bezpośrednio interpretacji źródeł przywołanych w przyp. 5: E. VolerRa, Per la storia di reato di bigamia in diritto romano, [w:] Studi in memoria di Umberto Ratti, Milano 1934, s. 397 [= Scritti giuridici, VII, Napoli 1999, s. 217] (należy przy tym zauważyć, że Volterra chyba zbyt jednoznacznie wnioskuje z tekstu Cycerona o nieistnieniu bigamii w rzymskim prawie przedklasycznym: nie bardzo można zrozumieć sensowność argumentacji Krassusa w cytowanym dialogu, przyjąwszy, że wszyscy w jego czasach zgadzali się, iż nowe małżeństwo rozwiązuje automatycznie poprzednie); TeNŻE, La conception du mariage d'après les juristes romains, Padova 1940, s. 59 [= Scritti giuridici, II, Napoli 1991, s. 61] TENŻE, Lezioni di diritto romano. Il matrimonio romano ${ }^{2}$, Roma 1961, zwłaszcza. s. 206-224; 154-5 i 294-96. Contra, ale mało przekonująco: J. Huber, Die Ehekonsens im römischen Recht, Roma 1977, s. 57-63. Por. też P.E. Corbett, The Roman Law of Marriage, Oxford 1930 (Aalen 1970), s. 225; M. LaUria, Matrimonio e la dote 2 , Napoli 1952, s. 47; A. Watson, The Law of Persons in the Later Roman Republic, Oxford 1967, s. 54; O. RoBledA, El matrimonio en derecho romano, Roma 1970, s. 118 i 261.

${ }^{5}$ Oczywiście podstawe znaczenie ma tu interpretacja przekazu Cycerona o możliwym rytuale rozwodu utrwalonym przez Ustawę XII Tablic (Cic.. Phil. 2,28,69: nolite quaerere; frugi factus est: mimulam suam rem sibi habere iussit ex XII tabulis claves ademit exegit.) oraz fragmentów De oratore opowadającym historię 
muły rozwodu stanowią residuum tych właśnie magiczno-rytualnych wymogów. Nie ma jednak wątpliwości, że przynajmniej od chwili uwiecznionej przekazem Cycerona, to jest zapewne drugiej połowy drugiego wieku p.n.e. ${ }^{6}$, dla prawnej ważności rozwodu nie miało znaczenie wypowiedzenie uświęconych tradycją słów res tuas habeto. Potwierdzenie tej tezy niezwykle łatwo odnaleźć w przedstawianych w pierwszych części artykułu podstawowych źródłach świadczących o nieformalności rozwodu w epoce klasycznej (D. 23,2,33, D. 24,1,64; 24,2,3; D. 25,2,11 pr. oraz Frag. Vat.106-107).

Źródła te jednak nie poddają się zupełnie oczywistej interpretacji. Najpoważniejszym problemem badawczym jest tu uzgodnienie ich rozumienia z informacją Swetoniusza o nałożeniu przez Augusta jakiegoś bliżej nieokreślonego modus na rozwody ${ }^{7}$ oraz niezwykle interesujacym fragmentem z komentarza Paulusa do Ustawy Julijskiej o cudzołóstwach (D. 24,2,9), zdającym się - prima facie - wskazywać na istnienie ściśle ustalonej procedury rozwodowej.

kontrowersji dotyczącej porzuconej hiszpańskiej żony (I 40,183 i I 56,238), a także liczne źródła literackie i prawne przekazujące formułę res tuas habeto. (D. 24,2,2,1 [Gai. 11 ad ed. prov.]: in repudiis autem, id est renuntiatione comprobata sunt haec verba: „tuas res tibi habeto”, item haec: „tuas res tibi agito”. Plaut., Amphyt. 928: valeas, tibi habeas res tuas. reddas meas; Plaut., Trin. 266: tuas res tibi habeto; Sen.,

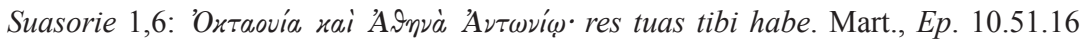
quae tua sunt, tibi habe: quae mea, redde mihi; Pseudo-Quinti., Decl. 262: res suas sibi habere iuberi; egredi de domo iuberi; Apul., Meth. 5.26: obi istud tam dirum facinus confestim toro meo divorte tibique res tuas habeto.

${ }^{6}$ Rzeczywistą datę dialogu ustala się zazwyczaj na wrzesień 91 p.n.e. Historia przypomniana przez Krassusa, która zdażyła się ,,za pamięci ojców”, memoria patrum, musiała zatem wydarzyć się pokolenie lub dwa wcześniej.

${ }^{7}$ Suet., Aug. 34: Leges retractavit et quasdam ex integro sanxit, ut sumptuariam et de adulteriis et de pudicitia, de ambitu, de maritandis ordinibus. Hanc cum aliquanto severius quam ceteras emendasset, prae tumultu recusantium perferre non potuit nisi adempta demum lenitave parte poenarum et vacatione trienni data auctisque praemiis. [2] Sic quoque abolitionem eius publico spectaculo pertinaciter postulante equite, accitos Germanici liberos receptosque partim ad se partim in patris gremium ostentavit, manu vultuque significans ne gravarentur imitari iuvenis exemplum. cumque etiam inmaturitate sponsarum et matrimoniorum crebra mutatione vim legis eludi sentiret, tempus sponsas habendi coartavit, divortiis modum imposuit. 
Przeczytajmy ten podstawowy tekst, nie wchodząc na razie głębiej w jego intepretację, a zwracając jedynie uwagę na jego umiejscowienie w systematyce Digestów justyniańskich - to jest w tytule o rozwodach 24 księgi:

D. 24,2,9 (Paul. 2 de adult.): Nullum divortium ratum est nisi septem civibus Romanis puberibus adhibitis praeter libertum eius qui divortium faciet. Libertum accepimus etiam eum, qui a patre avo proavo et ceteris susum.

Jak widzimy, jurysta stwierdza, że żaden rozwód nie może być uznany za ważny, jeśli nie został dokonany w obecności siedmiu świadków, dojrzałych obywateli rzymskich. Druga część źródła neguje zdolność poświadczenia aktu wyzwoleńcowi rozwodnika ${ }^{8}$. Co dokładnie miał na myśli Paulus postaram się ustalić po przedstawieniu wspomnianych źródeł, które przemawiają za brakiem jakiejkolwiek procedury99.

\section{NIEFORMALNOŚĆ ROZWODU: PODSTAWOWE PRZESŁANKI ŹRÓDŁOWE}

Od czasów Volterry w doktrynie przeważa mniemanie, że by rozwiązać małżeństwo - czy za obopólną zgodą małżonków, czy też

${ }^{8}$ Co do takie znaczenia zdania praeter - fin. por. już R. SCHLESINGER, Ueber die Form der Ehescheidung bei den Römern seit der 'lex Iulia de adulteriis', «ZSS» 5 (1866), s. 193-218, zwł. s. 197-199 oraz nieco bardziej współcześnie D. Noy, A Misunderstanding about Roman Divorce Law: The Meaning of 'praeter' in Digest 24.2.9, «Classical Quarterly» 38 n.s. 82 (1988), s. 572-576, krytycznie wobec thumaczenia Digestów dokonanego pod kierunkiem A. Watsona. Do argumentów filologicznych przedstawionych przed tego autora dorzuć można następującą konstatację, wykazującą absurdalność inkluzywenego rozumienia „praeter”. Jeśli zaiste zdanie to znaczyłoby "takes place in presence of seven Roman citizens of full age, as well as the freedman of the persons seeking divorce“, jak można byłoby sobie wyobrazić zgodny z Ustawą rozwód rozwodnika, który nie ma żadnego wyzwoleńca?! Znaczenie praeter potwierdza również konfrontajcą z wersją grecką fragmentu, Bas. $28,7,15$, gdzie odpowiada mu przyimek $\chi \omega \rho i$ s. „Praeter” zrozumiał błędnie także O. RoBledA, El matrimonio, cit., s. 261 i przyp. 58.

${ }^{9}$ Ogólnie o tych, zob. E. Volterra, Per la storia, cit., s. 396-401; 417-419 [= s. 216-221; 237-239]. 
jednostronnie, wystarczyło przestać chcieć pozostawać w związku małżeńskim: w ujęciu Volterry, rozwód jest zatem wygaśnięciem affectio maritalis $^{10}$. Należy jednak pamiętać, że zwolennicy przeciwnej tezy, to jest że małżeństwo w prawie rzymskim opierało się li tylko na zgodzie początkowej, proponowali diametralnie różną interpretację źrode ${ }^{11}$. Ich zdaniem przekonanie Volterry wzrusza lektura cytowanego przed chwilą komentarza Paulusa do lex Iulia de adulteriis (D. 24,2,9). Pomysł strony przeciwnej na uzgodnienie poniżej analizowanych tekstów z D. 24,2,9 oraz Suet., Aug. 34 opiera się na bardzo prostym założeniu: wszystkie źródła zdające się sugerować nieformalność rozwodu w czasach klasycznych świadczą o czymś zgoła przeciwnym. Autorzy klasyczni nie wspominają o dochowaniu formalności, przyjmując to za oczywistą daną: w przeciwnym razie nie możnaby mówić w ogó-

${ }^{10}$ Por. choćby E. Volterra, Per la storia, cit., s. 397; Tenże, Il matrimonio cit., s. 295-296. Czytelnik polski może zapoznać się poglądami Volterry w opracowaniu recenzyjnym fundamentalnej pracy włoskiego autora, La conception du mariage à Rome, W. WoŁodkiewiczA, «CPH» 9.2 (1957), s. 333-341. Historię badań nad małżeństwem rzymskim przedstawia W. RozWADowski, Nowe badania nad istota matżeństwa rzymskiego, «Meander» 42.4-5 (1987), s. 237-247 oraz TENŻE, Istota matżeństw w starożytnym Rzymie, «Gdańskie Studia Prawnicze» 14 (2005), s. $773-784$.

${ }^{11}$ By uświadomić sobie, jak różna może być interpretacja tych tekstów wystarczy zajrzeć do pracy podstawowego oponenta Volterry w czasach najnowszych, Olisa RoBleDy, który przedstawione poniżej źródła czyta w kluczu własnej teorii zgody początkowej, por. El matrimonio, cit., s. 121-125; 261-263. W zaskakujący sposób Riccardo Astolfi starał się natomiast pogodzić ogień z wodą, przyjąwszy, że małżeństwo rzymskie powstaje w wyniku wyrażenia zgody początkowej, a trwa dzięki affectio maritalis (por. op. cit., s. 26-43, oraz s. 44-45). Nie wydaje mi się zasadne szukanie dogmantycznego rózróżnienia między dwoma „zgodami“ na podstawie fragmentu pracy dotyczącej hipoteki Gaiusa, D. 20,1,4 = D. 22,4,4. Szerzej na ten temat napiszę w przygotowywanej recenzji książki Astofliego. Na marginesie trzeba przy tym zauważyć, że nie przekonują podtrzymane przez tego autora obiekcje co do autentyczności partii finalnej tekstu zasugerowane przez R. ORestano (Matrimonio, cit., s. 256). Wydaje się mało prawdopodobne, że przy ewidentym niedopatrzeniu kompilatorów jakim było umieszczenie tego samego tekstu dwa razy w Digestach, udało im się dokonać identycznych zmian w obu leges gemminatae. 
le o prawnym rozwodzie ${ }^{12}$. Pamiętajmy o tym poglądzie, czytając poniżej przytoczone wyimki z prac jurystów; mam wrażenie, że nawet ich pobieżna lektura pokaże, jak bardzo absurdalna jest to supozycja.

Najbardziej chyba oczywisty passus mówiący o braku formalności rozwodowych to fragment z Komentarza do Edyktu Ulpiana dotyczący stosowania actio rerum amotarum:

D. 25,2,11 pr.(Ulp. 33 ad ed.): Marcellus libro octavo digestorum scribit, sive vir uxorem sive uxor virum domi expulit et res amouverunt, rerum amotarum teneri.

W swym komentarzu Ulpian idzie za Marcellusem, przyznając actio w przypadku, gdy jedno z małżonków wyrzuciwszy drugie z domu, przywłaszczy sobie rzeczy należącego do byłego partnera. Przyjąwszy, że wytoczenie tej skargi nie jest możliwe bez uprzedniego rozwodu ${ }^{13}$, zauważyć możemy, że rozwód nie wymaga żadnej formalności, dokonuje się przez samo wyrzucenie współmażonka z domu. Mimo lakoniczności źródła możemy sądzić, że reaguje ono na historie, które dziś pewnie znalazłyby się na pierwszych stronach tabloidu: zwróćmy zwłaszcza uwagę na to, że rozważa się i możliwość wyrzucenia męża przez kobietę. Doprawdy trudno sobie wyobrazić, że aktowi temu towarzyszyła cała zalecana przez D. 24,2,9 procedura.

Rzeczywiste zdarzenie zainspirowało następne z naszych źródeł. Występujące $\mathrm{w}$ nim osoby i ich małżeńskie perypetie znane były doskonale czytelnikom rzymskich jurystów ${ }^{14}$.

${ }^{12}$ Por. R. Astolfi, op. cit., s. 314-315.

${ }^{13}$ Por.np. D. 24,2,11,2 (omówione szerzejponiżej, s. 100-102), D. 25,2,1, oraz A. WACKE, 'Actio rerum amotarum', Köln-Graz 1963, passim, zwł. s. 43 oraz s. 73-76. Krytyk omawianego fragmentu. J. HuBER, op. cit., s. 151-152, nie jest w stanie przekonująco uzasadnić, wjaki sposób to źródło mogłby uzasadnić preferowaną przez siebie teorię zgody początkowej.

${ }^{14}$ Por. Sen., dial. 1,3,10 (de providentia): Feliciorem Maecenatem putas, cui amoribus anxio et morosae uxoris citidiana repudia deflenti, somnus per symphoniarum cantum ex longiquo lene resonantium quaeritur?), oraz Ep. 114,6; Hor., Carm. 2,12; Suet., Aug. 66,3. O historycznym aspekcie źródła zob. literaturę zebraną w W. EvENEPOEL, Maecenas: A Survey of Recent Literature, «Ancient Society» 21 (1990), s. 99-117, oraz szkic A. GuARINO, Mecenate e Terenzia, «Labeo» 38 (1992), s. 137-146. 
D. 24,1,64 (Iav. 6 ex post. Lab.): Vir mulieri divortio facto quaedam idcirco dederat, ut ad se reverteretur: mulier reversa erat, deinde divortium fecerat. Labeo: Trebatius inter Terentiam et Maecenatem respondit si verum divortium fuisset, ratam esse donationem, si simulatum, contra. Sed verum est, quod Proculus et Caecilius putant, tunc verum esse divortium et valere donationem divortii causa factam, se aliae nuptiae intersecutae sunt aut tam longo tempore vidua fuisset ut dubium non foret alterum esse matrimonium: alias nec donationem ullius esse momenti futuram.

Opuszczony przez żonę mąż podarował jej coś, by skłonić ją do powrotu. Kobieta, choć w pierwszym momencie powróciła, niebawem ponownie porzuciła partnera. Problem prawny, z którym borykają się juryści jest oczywisty, wskazuje nań tytuł, w którym kompilatorzy umieścili fragment (D. 24,1: o darowiznach między matżonkami). Jak wiadomo, Rzymianie nie dozwalali na darowizny między małżonkami; jeśli zatem uznać, że pierwszy rozwód pary nie był rozwodem rzeczywistym (na co wskazywać by mógł fakt rychłego powrotu kobiety), darowizna nie miała miejsca. Cytowany przez Jawolenusa Labeo przypomina, jak w przypadku podarunku wręczonego przez Mecenasa przysłowiowo niestałej Terencji, Trebatius wskazał, że należy zbadać prawdziwość rozwodu. Divortium verum dopuszczało prawidłową darowiznę, divortium simulatum czyniło ją nieskuteczną. Jak z dużym prawdopodobieństwem uważa Guarino ${ }^{15}$, Trebatius udzielił tego responsum na pytanie samego Augusta, dziedzica Mecenasa, już po śmierci tego ostatniego. Z pewnością rzecz wręczona Terencji nie była błahostką, a princepsowi chętnemu zawsze, by odzyskać to, co mu się należało (por. Suet., Aug. 66), zależało, by uznać pierwszy rozwód niezwykle zamożnego testatora za nieważny i windykować dobra podarowane Terencji. Astolfi omawiając ten przypadek zakłada, że przy pierwszym (i drugim) rozwodzie z pewnością dochowano opisanej w D. 24,2,9 procedury: inna interpretacja wydaje mu się niemoż-

${ }^{15}$ A. Guarino, Mecenate e Terenzia, cit., s. 146. 
liwa przy przyjętym założeniu, iż norma ,nullum divortium..." miała charakter generalny ${ }^{16}$. Szereg zacytowanych przez Jawolenusa jurystów miałby się zatem zajmować problemem symulacji rozwodu dokonanego wobec siedmiu świadków (bo, jak pisze Astolfi, obowiązek obecności siedmiu mężczyzn przy rozwodzie zaledwie utrudniał pozorowanie rozwodu). Doprawdy, takie odczytanie źródła wydaje się absurdalne. Przy czynności dokonanej wobec świadków, nierzeczywistość aktu należałoby niezwykle solidnie wykazać - możemy mówić o domniemaniu prawdziwości czynności z dołączonym świadectwem osób w niej uczestniczących; trudno sobie zatem wyobrazić, że żaden z jurystów wymienionych w naszym tekście w ogóle nie wspomina o rozbieżności świadectw ze stanem rzeczywistym. Przeciwnie, przywołani w drugiej części źródła Prokulus i Caecilius wskazują jedynie na okoliczności, które mogą nas utwierdzić w przekonaniu, że faktyczna sepracja męża i żony naprawdę była tożsama $\mathrm{z}$ rozwodem ${ }^{17}$. Świadczy zatem o prawdziwości rozwodu: 1) nowe małżeństwo któregokolwiek z partnerów, jak i 2) długie pozostawianie kobiety samotnej pomiędzy dwoma małżeństwami ${ }^{18}$.

${ }^{16}$ R. Astolfi, op. cit., s. 314-315.

${ }^{17}$ Angielskie tłumaczenie Digestów pod red. A. Watsona sugeruje, że Proculus i Caecilius przeciwstawiają się zdaniu Labeona/Trebatiusa (,,but the opinion of Proculus and Caecilius is correct ...", tymczasem jest oczywiste, że jest to rozwinięcie i dopełnienie rozumowania z pierszej części tekstu. $Z$ tej to przyczyny nie wydaje mi się też koniecznie doszukiwanie się w naszym fragmencie kontrowersji między sabiniańską i prokulejańską szkołą prawa, jak chcieli E. LEvy, Der Hergang der römischen Ehescheidung, Weimar 1925, s. 87; 89-90 oraz za nim R. YARON, 'De divortio varia', «TR» 32 (1964), s. 535-537. Yaron uważał także, że komplitorzy zmodyfikowali oryginalny tekst, kierując się ewidentnie post-klasycznym favor nuptiarum - wydaje się, że tego typu podejrzenie nie znajduje uzasadnienia. Do problemu wrócę poniżej, s. 118-120, ale już teraz można zauważyć, że nasze teksty świadczą raczej o domniemania istnienia małżeństwa. Taka idea równoważy szalenie niepraktyczną zasadę affectio maritalis. Nie mogę się także zgodzić z pomysłem A. Guarino, Mecenate e Terenzia, cit., s. 140, który postulował, że małżeństwo byłoby prawdziwie rozwiązane jedynie w przypadkach opisanych w dodatku do responsum Trebatiusa.

${ }^{18}$ Na koniec trzeba przypomnieć zupełnie skrajną opinię Ernsta LEVY'EGO, op. cit., s. 86- 
Omówione właśnie źródło należy do grupy tekstów, których głównym motywem jest powrót do siebie skłóconych małżonków. Jeśli ich niezgoda jest trwała, małżonkowie rozchodzą się w gniewie i nigdy już do siebie nie wracają, to bez żadnych wątpliwości możemy mówić o rozwodzie. Problematyczne staje się późniejsze pogodzenie się małżonków. Czy ich zejście należy potraktować jako nowy związek, czy też jako kontynuuację nigdy nieprzerwanego pierwszego? Odpowiedź na to pytanie determinuje niezwykle istotne kwestie praktyczne, jak to pokazuje D. 24,1,64. Pytanie postawione przez jurystów daje się zrekonstruować następująco: czy można uznać za ważną darowiznę poczynioną przez jedno z małżonków na korzyść drugiego w czasie pomiędzy kłótnią i pogodzeniem się, w sytuacji zwłaszcza gdy nasze źródła wyraźnie akceptują darowizny poczynione z okazji rozwodu ${ }^{19}$.

Kolejny tekst, którym przychodzi nam się zajać, D. 24,2,33, dotyczy aktu prawnego, który z trwaniem małżeństwa wiązał niezwykle ważkie skutki: Ustaw Julijsko-Papijskich o zawieraniu matżeństw. Ustalenie trwania związku miało znaczenie dla decyzji, czy zainteresowanej osobie udało się spełnić wymogi Ustaw - być może, by stwierdzić, czy beneficjentowi należało się całe przyspożenie testamentowe, czy też nie. Pozostający w celibacie naturalnie nie mógłby wystapić o realizację zapisu, zaś ten, czyje małżeństwo trwało, miał prawo się go domagać.

D. 23,2,33 (Marcel. 1 ad leg. Iul. et Pap.): Plerique opinatur, cum eadem mulier ad eundum virum revertatur, id matrimonium

95, że cytowany fragment daje wyraz „bizantyjskiej teorii ustalenia zamiaru rozwodu”.

${ }^{19}$ Por. też zasady wzięte z komentarza Ulpiania do oratio Antonini et Severi, której głównym celem było złagodzenie zakazu darowizn między małżonkami: D. 24,1,32,10-11 (Ulp. 33 ad Sab.): Si divortium post donationem intercessit aut prior decesserit qui donum accepit, veteri iuri statur, hoc est, si maritus uxori: onatum vult, valeat donatio, quod si non vult, exstinguitur: plerique enim cum bona gratia discedunt, plerique cum ira sui animi et offensa. 11. Quid ergo, si divortium factum est, deinde matrimonium restauratur, et in divortio mutata est voluntas vel eandem duravit, restaurato tamen matrimonio et voluntate donatoris reconcilliata an donatio duret, si constante matrimonio donator decesserit? Et potest defendi valere. 
idem esse. Quibus adsentior, si non multo tempore interposito reconciliati fuerint nec inter moras aut illa alii nupserit aut hic aliam duxerit, maxime si nec dotem vir reddiderit ${ }^{20}$.

Marcellus modyfikuje opinię sporej części jurystów, że jeśli ta sama kobieta powraca do tego samego mężczyżny, mamy do czynienia z tym samym małżeństwem. Długa separacja, małżeństwo z inną osobą, a zwłaszcza zwrot posagu, zdaniem Marcellusa, falsyfikują to mniemanie. Druga część źródła - tak jak było to w przypadku dodatku Proculusa i Caeciliusa w D. 24,1,64 - wskazuje na przesłanki pozwalające ustalić, czy rozstanie się małżonków było równoznaczne z rozwodem. Choć w tym przypadku oczywiście celem jest ustalenie, czy zainteresowana osoba podpadała pod sankcje leges Iulia et Papia, a nie ważność darowizny, sens źródła jest taki sam: jurysta ex post facto stara się stwierdzić istnienie małżeństwa. Podobne postępowanie nie miałoby uzasadnienia, gdyby określony akt oznaczał koniec związku.

Kolejny problem praktyczny związany z ustaleniem rozwodu odnajdujemy w fragmencie responsów Paulusa we Fragmenta Vaticana:

Frag.Vat. 106-107 (Paulus, 8 responsorum): Convenit in pacto dotali,utdivortiofactosextaeliberorumnomineretinerentur: quaero, an discidio interveniente sextae retineri possint. Paulus respondit secundum ea quae proponuntur posse.

${ }^{20}$ E. Levy, op. cit., s. 88 przyp. 1, uznał tekst ten za interpolowany, wyrzucając jako nieklasyczne jego początek (plerique opinantur) oraz koniec (maxime - fin.). Pierwsza domniemana modyfikacja nie zmienia sensu tekstu. Argumentacja przemawiająca za drugą (przyjęta przez Astolfiego, op. cit., s. 308) nie wydaje się przekonywająca: zgadzam się z Levy'm, że nieoddanie posagu nie daje jeszcze ostatecznej podstawy, by uważać małżeństwo sprzed i po kłótni za tożsame, zauważmy jednak, że celem jurysty jest jedynie danie pomocniczych, a nie niezwruszalnych wskazówek do ustalenia rozwodu. Weryfikacja każdej z przesłanek potwierdza zatem rozwód: tak w przypadku oddania posagu, jak innych wymienionych sytuacjach. Nie przekonuje również argumentacja, że glosę maxime - fin. uprawdopodabnia porównanie z D. 24,1,64. Jak już pisałem powyżej, podane przez Proculusa i Caeciliusa dwa przypadki, mają tylko funkcję pomocniczych egzemplifikacji, a nie zamkniętego katalogu przypadków (por. Astolfi, op. cit., s. 308 przyp. 26). 
[107] Item quaesitum est, si vir repudium misit et eandem reduxit eaque mulier absente viro de domo eius discesserit, an aeque sextae retineri possint ex priore pacto. Paulus respondit, si verum divortium intercessit et ad eundem rursum reversa non renovato pacto man[en] te dote divortit, sextas liberorum nomine ita demum retineri posse, si culpa mulieris divortium intercessit.

Źródło zajmuje się interpretacją porozumienia posagowego zawartego przy okazji małżeństwa. Uwzględniono, że mąż zatrzyma sobie 1/6 posagu na wychowanie dzieci w przypadku rozwodu. Frag.Vat. 106 prawdopodobnie pomija dodatkowe informacje zawarte $\mathrm{w}$ pytaniu, w obecnym stanie zachowania źródła nie możemy dobrze zrozumieć natury problemu: responsum wyłącznie przychyla się do przedstawionej - jak się wydaje - zupełnie nie problematycznej hipotezy ${ }^{21}$. Z ko-

${ }^{21}$ E. Levy, op. cit., s. 7-8, thumaczył tę dziwną okoliczność faktem, że w responsum z Frag.Vat. 106 jurysta uznał za skuteczne pactum dokonane na okoliczość divortium także w przypadku discidium - wyjścia z domu. $Z$ tej obserwacji niemiecki romanista wnioskował, że zwykłe „odejście od siebie“ (discendere) jest tożsame z rozwodem (divortium). Podobne wnioski można wysnuć z lektury D. 24,1,57 (o tym źródle por. też. E. LEVY, op. cit., s. 6-7): ... si ser me meosque mores quid steterit, quo minus in diem vitae nostrae matrimonium permaneat, sive invito te discessero de domo tua vel repudium tibi sine ulla querella misero divortiumque factum per me probabitur ... . Widzimy, że rozwiązanie małżeństwa (,gdyby to się stało z mej przyczyny lub obyczajów, że małżeństwo nie dotrwa do kresu naszego życia“) może dojść do skutku na trzy równoznaczne sposoby: (1) kobieta może odejść z domu męża, wywołując rozwód (discendere de domo); (2) wysłać mężowi list rozwodowy bez powodu (repudium mittere); albo (3) skłoni męża swym postępowaniem do dokonania rozwodu (divortium: źródło nie rozróżnia ty bynajmniej pomiędzy rozwodem jednostronnym, a za obopólną zgoda). Inaczej, R. YAron, 'Minutiae' on Roman Divorce, «TJ» 28 (1960), s. 10-11. Natomiast, P.E. CORBETT, op. cit., s. 234, upatrywał problemu z interpretacją pactum w tym, że byłoby ono zawarte z naruszeniem interesu kobiety: 1/6 to zwykła część posagu zatrzymywana przez męża pozwanego z actio rei uxoriae na każde z dzieci po rozwodzie zawinionym przez kobietę lub jej zwierzchnika familijnego (por. Ulp. 6,9-10: Retentiones ex dote fiunt [aut propter liberos] aut propter moras aut propter impensas aut propter res donatas aut propter res amotas. [10] Propter liberos retentio fit, si culpa mulieris aut patris cuius in protestate est divortium factum sit: tunc enim singulorum liberorum nomine sextae retinentur ex dote, non plures tamen quam tres); 
lei w $\S 107$ przedstawiono następującą sytuację związaną ze stanem faktycznym z $\S 106$, przypominająca jako żywo powiastkę Brzechwy Czapla i żuraw. Mąż rozwiódł się z żoną i następnie ponownie ją poślubił. Potem to kobieta opuściła mężczyznę w czasie jego nieobecności. Pytanie postanowione juryście jest oczywiste: czy zawarte przy ustanowieniu posagu porozumienie o zatrzymaniu przez męża 1/6 na wychowanie dzieci, wiąże strony po kolejnym rozwodzie. Paulus odpowiedział, że jeśli którykolwiek z rozwodów był prawdziwy (verum), mąż będzie mógł zatrzymać sobie część posagu tylko, jeśli kolejny rozwód dokonał się z winy żony. Nie trudno wyjaśnić tę decyzję: po pierwszym (prawdziwym) rozwodzie pactum traci moc, mąż zatem może zatrzymać sobie część posagu tylko na zasadach ogólnych opisanych w Ulp. 6,9-10 (cyt. w przyp. 21). Ponownie mamy do czynienia zatem z tym samym problemem prawnym: niezwykle trudno ustalić realność rozwodu. Dlaczego? Bo nie towarzyszą mu żadne czynności dodatkowe. Niezwykle trudno sobie wyobrazić, że zwłaszcza odejście kobiety pod nieobecność męża miało przepisaną przez D. 24,2,9 oprawę (Astolfi w ogóle zresztą nie analizuje świadectwa Frag.Vat. 107 pod tym względem).

W przeglądzie źródeł, które - podtrzymuję, wbrew tezie Astolfiego - świadczą o nieformalności rozwodu w prawie klasycznym, przychodzi nam teraz zająć się tekstem, który na pierwszy rzut oka oraz wedle części doktryny, zdaje się przeczyć dotychczas ustalonym faktom $^{22}$. W D. 24,2,3 $3^{23}$ Paulus przypomina, że nie każda kłótnia skutkuje rozwodem:

uprawnienei męża do zachowania $1 / 6$ posagu w każdym przypadku mogłoby naruszać "common law" chroniące interesy kobiety. Por. też Frag.Vat. 120, w którym zdaje się być powtórzony podobne rozumowanie - źródło jest niestety zbyt fragmentaryczne, by satysfakcjonująco je analizować.

${ }^{22}$ Por. np. J. Huber, op. cit., s. 57-58, który zresztą zupełnie niesłusznie przypisuje terminowi repudium znaczenie rozwiązania małżeństwa w sposób formalny. Ale jurysta nie mógł mieć tego na myśli: wszak cały tekst dotyczy niedokonanego rozwodu.

${ }^{23}$ Skróconą wersję tego samego passusu odnajdujemy w D. 50,17,48 (Paul. 35 ad ed.: quidquid in calore iracundiae vel fit vel dicitur, non prius ratum est, quam si perseverantia apparuit iudicium animi fuisse. ideoque brevi reversa uxor nec 
D. 24,2,3 (Paul. 35 ad ed.): Divortium non est nisi verum, quod animo perpetuam constituendi dissensionem fit. Itaque quiduid in calore iracundiae vel fit vel dicitur, non prius ratum est quam si perseverantia apparuit iudicium animi fuisse: ideoque per calorem misso ripudio si brevi reversa uxor est, nec divertisse videtur.

Czytamy zatem, że rozwód dokonany bez chęci wywołania trwałego zerwania nie może zostać uznany za prawdziwy ${ }^{24}$. A zatem, ciągnie Paulus, wszystko, co powiedziano podczas kłótni, we wzburzeniu, nie wywołuje rozwodu, póki trwanie w separacji nie wykaże, że takie rzeczywiście było iudicium animi małżonka. Z tego stwierdzenia wynika ostatnie zdanie źródła: choć wysłano list rozwodowy, nie ma on skutków, jeśli żona wkrótce wraca do męża. Ernst Levy uznał to źródło za interpolowane, doszukując się w nim bizantyjskiej teorii potwierdzenia woli rozwodu ${ }^{25}$. Nie wydaje mi się to konieczne. Przyjęcie przez jurysprudencję klasyczną rozwiązania przeciwnego - to jest, że każdy, nawet najmnieszy, spór skutkuje utratą affectio - byłoby niezwykle niepraktyczne. Za klasycznością tekstu przemawiają także wszystkie dotychczas przeanalizowane źródła ${ }^{26}$.

divortisse videtur). Niestety nie umiemy dokładnie ustalić kontekstu palingenetycznego tekstu Paulusa. O. Lenel, Palingenesia, I, Lipsiae 1889, col. 1040-1041, oczywiście umieszcza go wraz z innymi fragmentami 35 księgi komentarza do Edyktu; można z nich jedynie wywnioskować, że księga ta dotyczyła małżeństwa i rozwodu.

${ }^{24}$ „Verum" jako określenie rozwodu należałoby zatem rozumieć w świetle naszych źródeł jako ,rzeczywisty, ostateczny” - por. R. YARON, 'De divortio varia', cit., s. 542. Nie trzeba zatem w naszych źródłach doszukiwać się figury divortium simulatum: rozwód rzeczywisty jest zawsze ostateczny, akt symulowany po prostu nie jest rozwodem.

${ }^{25}$ E. LeVY, op. cit., s. 60-66; 88; 89-99.

${ }^{26}$ W 'Res tuas habeto', cit., s. 96-97, starałem się odczytać we frazie Itaque quiduid [...] vel fit vel dicitur pozostałość być może obecnego w czasach archaicznych, że samo wypowiedzenie opowiedniej formuły (res tuas habeto vel sim.) dokonywało rozwodu, bez względu na intencje stron. Wynika to perfomatywnej funkcji rytuału magicznoprawnego - podobnie rzecz ma się i dziś w rozwodzie wedle prawa koranicznego: bez względu na nastawienie mówiącego, trzykrotne wypowiedzenie zdania ,jesteś wolna”, 
Jest oczywiste, że tak, jak wszystkie dotąd analizowane źródła, i D. 24,3,2, potwierdza, że rozwód może się dokonać bez żadnych formalności. Gdyby tak nie było, nie sposób sobie wyobrazić, dlaczego w ogóle Paulus zajął się tym problemem. Gdyby trzeba spełnić jakieś przesłanki formalne, juryści nie musieliby się uciekać do wynajdowania pomocniczych przesłanek poświadczających o tym, że rozwód zaiste miał miejsce (zwrot posagu, długie rozstanie, nowe małżeństwo), ich odpowiedź zawsze dotyczyłaby dopełnienia lub nie przepisanych procedur $^{27}$.

Przegląd źródeł dotyczących nieformalności rozwodu, zakończymy analizą słynnego tekstu, często branego na warsztat przez Volterręe ${ }^{28}$ :

D. 24,1,32,13 (Ulp. 32 ad Sab.) Si mulier et maritus diu seorsum quidem habitaverint, sed honorem invicem matrimonii habebant (quod scimus interdum et inter consulares personas subsecutum), puto donationes non valere, quasi duraverint nuptiae: non enim coitus matrimonium facit, sed maritalis affectio: si tamen donator prior decesserit, tunc donatio valebit.

Fragment komentarza Ulpiana do oratio Antonini et Severi, którą cesarze łagodzili bezwględność zakazu darowizn między małżonkami, podkreśla, że nawet długie przebywanie osobno nie wpływa na trwa-

czyni żonę rozwódką. W naszym źródle Paulus zatem podkreślałby, że odkąd ugruntowała się istota małżeństwa jako wolnego, nieformalnego związku opartego na affectio, nawet wypowiedzenie uświęconej tradycją formuły nie prowadzi do zerwania związku, jeśli «wytrwałość» nie wykaże, że taka była rzeczywista intencja stron.

${ }^{27}$ Por. też D. 24,1,32,12: Quod si divortium non intercesserit, sed frivusculum, profecto valebit donatio, si frivusculum quievit. Oczywiście, jak cała lex D. 24,1,32, tekst ten w zasadzie dotyczy uznania za ważną - na mocy łagodzącej zakaz darowizn oratio Antonina i Sewera - darowizny poczynionej między małżonkami po śmierci jednego z nich, pod warunkiem, że nie ma przesłanek, by uznać, że darczyńca chciał ją odwołać. Przy okazji widzimy jednak, że na zewnątrz trudno odróżnić sprzeczkę od rozwodu.

${ }^{28}$ Por. choćby E. VolterRA, s.v. matrimonio (diritto romano), «ED» 25 [= Scritti giuridici, III, s. 245-246]; TeNżE, La conception du mariage d'après les jurists romaines, s. 45-50 [= Scritti giuridici, II, s 46-51] 
nie małżeństwa. By związek się kontynuuwał wystarczy, by partnerzy czuli honos invicem matrimonii: obowiązek małżeński względem siebie. Bo - jak mówi często powtarzany fragment źródła - małżeństwo tworzy nie współżycie, a affectio maritalis. Konstatacja tej przesłanki jest oczywista: nie dopuszcza się zatem darowizny między nieprzebywającymi ze sobą małżonkami. Sens tego źródła słusznie uchwycił Levy ${ }^{29}$ : jest to jeszcze jeden dowód na brak formalnści rozwodowych. Gdyby bowiem tak było, jurysta nigdy nie trudziłby się wyjaśnieniem, że nie każde, nawet długotrwałe, rozstanie małżonków należy interpretować jako koniec ich związku.

\section{BRAK BIGAMII JAKO DOWÓD NA NIEFORMALNOŚĆ ROZWODU}

Za brakiem procedury rozwodowej przemawiają także te źródła, które w opinii Volterry i jego następców dowodzą niemożliwości bigamii w rzymskim prawie klasycznym. Zawarcie nowego małżeństwa automatycznie rozwiązuje poprzednie ${ }^{30}$. Do takiego wniosku uprawniają przedstawione powyżej: D. 24,1,64; 23,2,33 oraz końcowy fragment D. 24,2,11,2. Lex 11 tytułu D. 24,2 zaczerpnięto z komentarza Ulpiana do ustaw małżeńskich Augusta. Dotyczy ona rozwodu wyzwolenicy.

D. 24,2,11,2 (Ulp. 3 ad leg. Iul. et Pap.): Illud rectessime placuit, qualiquali voluntate intellegi possit patronus animus habere desisse quasi in uxorem, finiri legis huius beneficium. Proinde cum patronus rerum amotarum cum liberta, quae ab invito eo divorterat, vellet experiri, imperator noster cum divo patre suo rescripsit intellegi eum hoc ipso nolle nuptam sibi, qui eam actionem vel aliam inportet quae non solet nisi ex divortio oriri. Quare si accusare eam adulterii coeperit vel alio crimine postulare, quod uxori nemo obicit, magis est, ut diremptum sit matrimonium: etenim meminisse oportet ideo adimi cum alio conubium, quia patronus sibi nuptam cupit.

${ }^{29}$ E. Levy, op. cit., s. $11 ; 85$.

${ }^{30}$ E. Volterra, Per la storia, cit. passim 
Ubicumque igitur vel tenuis intellectus videri potest nolentis nuptam, dicendum est iam incipere libertae cum alio esse conubium. Proinde si patronus sibi desponderit aliam vel destinaverit vel matrimonium alterius appetierit, credendus est nolle hanc nuptam: et si concubinam sibi adhibuerit, idem erit probandum.

W poprzedzających cytowany tekst paragrafach (D. 24,2,11 pr.-1), Ulpian, przypomniawszy wprowadzone przez Augusta ograniczenia rozwodu niewolnicy wyzwolonej w celu zamążpójścia za patrona, wyjaśnił sytuację prawną kobiety, która wbrew zakazowi jedstronnie zrywa związek z małżonkiem-patronem. Choć sam rozwód jest skuteczny - nawet August nie próbował zmienić zasady, że małżeństwa są wolne - kobieta nie może prawnie zawrzeć nowego małżeństwa, brak jej conubium ${ }^{31}$. Natomiast w przywołanym przed chwilą fragmencie Ulpian opisuje sytuacje, w których wyzwolenica odzyskuje conubium, mimo dokonanego wcześniej samowolnego rozwodu. Zdarza się to wtedy, gdy można domniemywać, że patron ex post przyzwolił na rozwód żony. Zgodę można wywnioskować z okoliczności zewnętrznych. Jurysta przywołuje reskrypt cesarski, przypominający, że kiedy mąż wytacza kobiecie skargę niedopuszcząlną między małżonkami (actio rerum amotarum) czy też oskarżenie karne (w tym accusatio adulterii) staje się jasne, że mężczyzna przestał chcieć być poślubiony swojej byłej niewolnicy. Na zgodę męża-patrona wskazuje także fakt zaręczenia się przez niego z inną kobieta, jego nowe małżeństwo, a nawet wzięcie sobie konkubiny. I znów, podobnie jak w źródłach opisanych w części pierszej, staje się oczywiste, że rozwodowi nie towarzyszą żadne formalności.

${ }^{31}$ Por. też potwierdzenie tej zasady w dwóch konstytucjach Aleksandra Sewera: C. 5,5,1: Liberta eademque uxor tua, si a te invito discesserit, conubium cum alio non habet, si modo uxorem eam habere velis; C. 6,3,9: Liberatae tuae ducendo eam uxorem dignitatem auxisti, et ideo non est cogendo operas tibi praestare, cum possisi legis beneficio contentus esse, quod invito te iuste non possit alii nubere. O rozwodzie wyzwolenicy patrz też-S. Solazzi, Studi sul divorzio: 2. Il divorzio della liberta, [w:] Scritti di diritto romano, III, (1925-1937), Napoli 1960, s. 21-32 [=«BIDR» 34 (1925), s. 295-319]; E. Levy, op. cit., s. 137-139 i E. Volterra, Sul divorzio della liberta, [w:] Studi Riccobono, III, Palermo 1936, s. 203-230 [= Scritti giuridici, I, Napoli 1991, s. 499-526]. 


\section{PRZESŁanKI POZWALAJĄCE USTALIĆ ROZWÓD W ANALIZOWANYCH ŹRÓDŁACH}

We wszystkich przeanalizowanych tekstach możemy znaleźć jedno podstawowe podobieństwo: w każdym przypadku ustala się post factum, czy doszło do rozwodu. Juryprudencja posługuje się wskazówkami pomocnymi dla stwierdzenia rozwodu. Sa nimi: nowozawarte małżeństwo (ale także zaręczyny z inną kobietą, albo zamieszkanie z konkubiną), oddanie posagu, wytoczenie skargi niedopuszczalnej między małżonkami, a także (choć to oczywiście najmniej pewna przesłanka), długotrwałe rozstanie. Wszystkie te przełanki wskazują, że nie jest możliwe przyjęcie powszechnego obowiązywania normy z D. 24,2,9.

\section{RozwóD Klaudiusza}

Zanim przejdziemy do analizy D. 24,2,9, źródła, z którego zdaje się wynikać diametralnie różna struktura rozwodu rzymskiego, od tej, którą starałem się odczytać w dotychczas interpretowanych tekstach, zatrzymajmy się przez moment nad jednym z motywów starożytnej opery mydlanej: małżeństwem Klaudiusza i Messaliny ${ }^{32}$. Przypominijmy okoliczności pamiętając, że nie sposób dokładnie ustalić, co stało się w roku 4833. Dla Seneki i Swetoniusza cała historia służy przede wszystkim do konstrukcji negatywnego topos cesarza,

32 Ostatnio na ten temat: A. Guarino, In difesa di Messalina, «Labeo» 20 (1974), s. 19-26. Neapoletański romanista użył do obrony Messaliny dość zaskakujących argumentów natury raczej psychologicznej i psychiatrycznej niż - niestety - prawnej: zachowanie cesarza, schizofrenika, nie potrafiącego zapewnić żonie ciepła w związku, całkowicie usprawiedliwiłoby postępowanie Messaliny. Patrz też O. Robleda, Cic. 'de orat.' 1.40.183; 56.238 [powinno być 283 - JU] y el divorcio de Messalina, «SDHI» 42 (1976), s. 424.

${ }^{33}$ Sprawę Gaiusa Sillusa i Messaliny, stanowiącą część niezbyt pochlebnego anegdotariusza o Klaudiuszu, opisuje wielu autorów starożytnych: Por. Sen., Apoc. 11,1-5; 13,4; Josephus Fl., Ant. 20,149; 20,336; Suet., Claudius 26,2; 29,3; 36; 39,1; Cass. Dio 40,31,1-5; Aur. Vict. 4,10-11; Tac., Ann. 11,26-38. 
człowieka okrutnego i słabego, nieodpowiedzialnego głupca niezdolnego do rządzenia państwem. Dla tych pisarzy cała sprawa to jeszcze jeden epizod erotycznych przygód Messaliny, ale z przekazu Tacyta możemy wnioskować, że propozycja małżeństwa z cesarzową mogła być częścią planowanego zamachu stanu, albo, że przynajmniej tak chciano ją cesarzowi przedstawićs ${ }^{34}$. To właśnie u tego historyka znajdujemy najbardziej szczegółowy opis sprawy. Messalina od pewnego czasu utrzymywała stosunki z konsulem desygnowanym na rok następny, młodym arystokrata, Caiusem Sillusem. Ten - bezdzietny i bezżenny - miał zaproponować Messalinie małżeństwo i adopcję jej dzieci ze związku z cesarzem. Para skorzystała z nieobecności Klaudusza w Rzymie. Kiedy cesarz udał się złożyć ofiary do Ostii, Messalina i Sillius zawarli małżeństwo z pełnym ceremoniałem (Tac., Ann. 11,26-27). Kiedy wieść się rozeszła, Narcyz, jeden z wszechmocnych wyzwoleńców cesarza, wziął na siebie powiadomienie patrona o zajściu. Zwróćmy uwagę na włożone w jego usta słowa:

Tac. Ann. 11,30: An discidium - inquit - tuum nosti? Nam matrimonium Silii vidit populus et senatus et miles; ac ni propere agis, tenet urbem maritus! „Czyż nie wiesz - rzecze - o twoim rozwodzie? Bo i lud, i senat, i armia zobaczyli małżeństwo Silliusa; a teraz, jeśli nic nie uczynisz, mąż podporządkuje sobie Miasto!“.

Nie ma znaczenia, czy rzeczywiście wyzwoleniec powiedział to, co przeczytaliśmy i czy w ogóle cała scena między nim a Klaudiuszem miała miejsce - zapewne zresztą mamy do czynienia z powstałą na użytek czytelników fikcją literacką. Jest dla nas ważne, że dla publiczności historiografa - i oczywiście dla niego samego - nowe małżeństwo stanowiło discidium, czyli zerwanie dawnego. W opisanej szczegółowo - co ma pokreślić wiarygodność narracji - historii nie mogłoby zabrak-

${ }^{34}$ Można wyciagnąc takie wnioski na podstawie informacji o wielkiej liczbie skazanych na śmierć wokół sprawy Messaliny (Ann. 11,35-36), oraz przypisanej Narcyzowi groźbie wobec cesarza, że jeśli nic nie uczyni ,[nowy] mąż podporządkuje sobie Miasto". 
nąć opisu aktu formalnego wobec siedmiu świadków, gdyby rzeczywiście był wymagany i miał miejsce. Jest zatem rozwód Klaudiusza i Messaliny jeszcze jedną przesłanką pozwalającą czytać źrodła prawne w zaproponowanym dotychczas kluczu: dowodów na nieformalność rozwodu w rzymskim prawie klasycznym.

\section{WYMOGI FORMALNE WOBEC ROZWODU}

WEDLE LEX IULIA DE ADULTERIS (D. 24,2,9)

Powróćmy zatem do przywołanego już we Wprowadzeniu źródła, starając się teraz odnalaźć jego właściwe znaczenie. Przypomnijmy, wedle komentarza Paulusa do Ustawy Julijskiej o cudzołóstwach jedynie prawny możliwie rozwód to taki, którego dokonuje się wobec siedmiu świadków. Doktryna - jak już wspominałem - łączy tę informację z przekazem Swetoniusza o nałożeniu przez Augusta modus na rozwody w ramach działalności cesarza zmierzającej do przywrócenia prawdawnych obyczajów.

Romaniści na różne sposoby starali się uzgodnić treść D. 24,2,9 z przedstawionymi w punktach II-IV danymi. Zanim przedstawię argumentację kolejnych badaczy, muszę sformułować uwagę natury ogólnej: każde wnioskowanie oparte na przekazie Swetoniusza będzie dość słabe. Krótki ten passus przede wszystkim nie daje nam żadnych bardziej szczegółowych danych pozwalających zrozumieć nieomylnie wyrażenie divortiis modum imponere, a zwłaszcza odczytać jego możliwe znaczenie techniczne. Nie można w ogóle spodziewać się, że biograf cesarski posługiwał się językiem technicznym. Błędne zatem jest odczytanie tego tekstu, tak jak byłby to wyimek samej ustawy. Zauważmy przy tym, że to wyrażenie można zrozumieć zarówno jako „postawić tamę“ (w tym sensie, że choć rozwody były nadal jak najbardziej dozwolone i nieobwarowane dodatkowymi przepisami, nakaz pozostawania w związku małżeńskim nałożony przez ustawy Augusta, zmierzał do ograniczenia ich liczby) lub „ustanowić sposób dokonania rozwodu“ (jako ustanowienie specjalnej, nowej procedury rozwodo- 
wej - być może przekazanej w D. 24,2,9 ${ }^{35}$. W każdym razie, wydaje się dość nieprawdopodobne, by ustawodawca rzeczywiście uważał, że wprowadzenie obowiązku siedmiu świadków zdecydowanie utrudni rozwody i położy im kres.

\section{DOKTRYNA A NORMA W D. 24,2,9: KIEDY STOSOWANA?}

W tej części artykułu przedstawię pomysły na interpretację przekazu paolińskiego na temat treści lex Iulia de adulteriis. Jak już miałem okazję wspomieć, najbardziej skrajny pogląd widzi w D. 24,2,9 normę o charakerze absolutnym, stosowaną w każdym przypadku rozwodu. Tak czytał ją R. Leonhard, Josef Huber ${ }^{36}$, Percy Elwood Corbett ${ }^{37}$, a ostatnio Riccardo Astolfi ${ }^{38}$. W interesujący sposób ci dwaj ostatni autorzy usiłowali uzgodnić prezentowane wcześniej źródła z D. 24,2,9. Jest dla nich oczywiste, że we wszystkich opisywanych powyżej przypadkach doszło do rozwodu w obecności siedmiu świadków! Wszędzie zatem, gdzie źródła mówią o ,discendere de domo”, „discidium”, „divortium facere" mielibyśmy dorozumianą asystencję świadków - juryści klasyczni zaś nie wspominali o dokonanym rytuale, gdyż było to tak jasne, że aż zbędne ${ }^{39}$. Wydaje mi się, że w wystarczający sposób

${ }^{35}$ Por. n.p. J. Huber, op. cit., s. 152-154, który naturalnie wybrał drugie rozumienie frazy.

${ }^{36}$ R. Leonhard, s.v. 'divortium', «RE»; J. Huber, op. cit., s. 151-159 i passim. Jak już wcześniej wspominałem, autor ten, rozwijając poglądy swego nauczyciela Olisa Robledy, starał się udodowodnić, że procedura rozwodowa, wprowadzona jak mniemał - przez Augusta, jest kolejnym dowodem na fałszywość tezy o zgodzie ciagłej jako tworzącej małżeństwo rzymskie. Huber podobnie - jak sądzę mylnie: por. Pater enim nuntium mittere posse, cit. passim - interpretował źródła, które mówią o wywołanym przez pater familias rozwodzie córki pod władzą.

${ }^{37}$ P. E. Corbett, op. cit., s. 228-239.

${ }^{38}$ R. Astolfi, op. cit., s. 312-329.

${ }^{39}$ Por. Conbett, op. cit., s. 235: „This proves nothing more then that dicedere de domo still means divorce in legal terminology, though act of abandoning the matrimonial domicile must now be accompanied by the declaration or notification attested by seven witnesses”; R. Astolfi, op. cit., s. 314: „la presenza dei testimoni 
udało mi się wykazać absurdalność tej tezy. Przypomnę podstawowe argumenty: kontekst źródeł wskazuje na opuszczenie współmałżonka w sposób nie zostawiający miejsca na ceremoniał rozwodowy; a gdyby nawet rzeczywiście rytuał odbył się w obecności siedmiu świadków, juryści musieliby jakoś sobie poradzić z problemem poświadczenia $d i$ vortium simulatum przez siedmiu obywateli, pomyłki w ich percepcji aktu między małżonkami. Jak widzieliśmy, nigdy tego nie robią.

$\mathrm{Z}$ tych samych powodów, mutatis mutandis, należy odrzucić poglądy tych autorów, którzy postulowali stosowanie normy nullum divortium ograniczone do pewnych przypadków. Pietro Bonfante, do którego pomysłu przychylili się Giannetto Longo i Olis Robleda, uważał, że ustawodawstwo Augusta nałożyło karby proceduralne na wszystkie rozwody jednostronne, identyfikowane przez tego autora z repudium ${ }^{40}$. Nie tylko kontekst cytowanych źródeł - a zwłaszcza D. 25,2,11 pr., gdzie wyraźnie mowa jest o wyrzuceniu jednego z małżonków przez drugie bez żadnych formalności - przemawia przeciwko takiej interpretacji. Dodatkowym argumentem jest faktyczna równoznaczność zwrotów repudium mittere oraz divortium facere ${ }^{41}$. Nie przekonuje również pomysł Bonfante wyjaśniający konsekwencje niezastosowania się do procedury rozwodowej (Longo i Robleda nie zajęli się w ogóle tą kwestią). Autor postulował, że choć bez świadków małżeństwo zrywano skutecznie (wszak po ustaniu affectio związek trwać nie może), byli małżonkowie tracili conubium (tak jak wyzwolenica rozwódka w D. 24,2,11,2). Zauważmy jednak, że nasze źródła jako jedną z przesłanek ustania poprzedniego małżeństwa podają zawarcie nowego (jak

non asicura che l'atto esprima una seria volontà di sciogliere il rapporto matrimoniale, né esclude simulazione [...] si spiega così perché durante tutta l'epoca classica la giurisprudenza continui a porsi il problema del verum divortium".

${ }^{40}$ Por. P. Bonfante, op. cit.; G. Longo, Diritto romano, diritto di famiglia, Roma 1953, s. 93-95 oraz O. RobledA, El matrimonio, cit., s. 261 i przyp. 58. Autor hiszpański widział, ja po nim Huber, w D. 24,2,9 dowód na poprawność teorii zgody początkowej.

${ }^{41}$ Por. E. Levy, op. cit., s. 76 przyp. 1; problemem tym zajmowałem się również w pierszym rozdziale mego jeszcze niepublikowanego doktoratu: § III: «Le definizioni e la terminologia del divorzio», s . 27-33. 
choćby w D. 23,2,33). Utrata zdolności zawarcia małżeństwa nie mogła zatem mieć miejsca. Zresztą gdyby tak było, byłaby to okoliczność tak istotna, że na pewno zostawiłaby jakieś ślady w omawianych źródtach tak, jak to uczyniono w D. 24,2,11,2 in fin.

W niezwykle interesującym i dogłębnym artykule Reuven Yaron $^{42}$ zaproponował inne odczytanie tekstu. Przeciwstawiając się - jak najbardziej słusznie - pomysłowi Ernsta Levy'ego ${ }^{43}$, że rozwód między nieobecnymi stawał się skuteczny tylko wtedy, gdy wiadomość o nim dotarła do rozwiedzionego partnera, uczony izraelski uznał, że właśnie $\mathrm{w}$ takim przypadku rozwód wymagałby formy $\mathrm{z}$ towarzyszeniem świadków. Takie rozwiązanie - zdanem Yarona, który zasugerował się kontekstem palingenetycznym źródła - wykluczałoby niebezpieczeństwo oskarżenia o adulterium i bigamię w przypadku nowego małżeństwa ${ }^{44}$. Uczony zapronował następującą korektę tekstu z Digestów: nullum <inter absentes> divortium ratum est nisi septem civibus etc. Rekonstrukcja jednakże nie tylko nie daje się uzasadnić tekstem oraz konfrontacją ze źródłami zdecydowanie przeczącymi istnieniu bigamii w rzymskim prawie klasycznym, ale również przeczy podstawowemu argumentowi Yarona przeciwko stworzonej przez Levy'iego teorii „Empfangsbedürftigkeit”"45.

Niemiecka doktryna w przeważającej części uznanała, że Ustawa Julijska przewidywała opisaną w D. 24,2,9 formę do dokonania remancypacji kobiety, pozostającej po rozwodzie pod manus eks-małżonka ${ }^{46}$, zwłaszcza w przypadku rozwodu z cudzołożnicą. Volker Schaub $^{47}$ uważał, że taka kobieta, pozostając pod władzą swego eks-

${ }^{42}$ R. YARON, 'Divortium inter absentes', «TR» 31 (1963), s. 54-68, na s. 59-60.

${ }^{43}$ E. LeVY, op. cit., s. 53-54; 83-86.

${ }^{44}$ R. YARON, 'Divortium inter absentes', cit. s. 59-60.

${ }^{45}$ S.54:,,thefact thatthedeclarationofdivorcerequiresreception, is 'empfangsbedürftig' [...], if correct, entails serious de facto limitations on the power of divorce".

${ }^{46}$ E. Levy, op. cit., zwłaszcza s. 38-41, 46 oraz tam cytowana literatura; P. JöRs, W. Kunkel, L. Wenger, Römisches Privatrecht ${ }^{3}$, Heidelberg 1949, s. 282 i przyp. 11.

${ }^{47}$ V. Schaub, Der Zwang zur Entlassung aus der Ehegewalt und die remancipatio ohne uxor, «ZSS» 82 (1965), s. 106-131, zwłaszcza s. 128-131. 
małżonka, wystawiała go na niebezpieczeństwo oskarżenia o crimen lenonocinii. Wedle Schauba cudzołożnice po rozwodzie mogłyby zatem dodatkowo zemścić się na mężach, unikając wyzwolenia spod manus. Procedura z siedmioma świadkami miała zatem służyć dokonaniu remancypacji kobiety bez jej udziału.

Rzeczywiście jednym z nierozwiązanych zagadnień teoretycznych dotyczących rzymskiego rozwodu jest problem remancypacji kobiety in manus mariti po rozwodzie. W przypadku obustronnego zerwania, które w dodatku odbyłoby sę bez zbyt wielkich komplikacji, nietrudno sobie wyobrazić, że były mąż dokonałby natychmiast aktu formalnego zwalniającego kobietę spod swej władzy ${ }^{48}$. Co jednak wtedy, gdy rozstanie małżonków było wyjątkowo burzliwe? Źródła nie dają żadnej odpowiedzi wprost, jak można było zmusić męża do remancypacji żony ${ }^{49}$, czy też byłą żonę do wzięcia udziału w akcie formalnym ${ }^{50}$. Na szczęście nie musimy zajmować się tutaj tym problemem: jak wiemy, małżeństwa połączone $\mathrm{z}$ conventio in manu mariti $\mathrm{w}$ czasach

${ }^{48}$ Por. Fest., de sign. verb. 74 (L. 65) lemmy: diffarreatio genus erat sacrificii, quo inter virum et mulierem fiebat dissolutio. Dicta diffarreatio, quia fiebat farreo libo adhibito e remancipatam; 277 (L. 342) remancipatam Gallus Aelius esse ait, quae mancipata sit ab eo, cui in manum convenerit.

${ }^{49}$ Por. V. Schaub, op. cit., s. 108-110; E. Levy, op. cit., s. 40; oraz , F. KNIEP (ed.) 'Gai institutionum commentarius primus', Text, mit Vorwort, Erklärung und Anhängen, Jena 1911, s. 238-241 (no 49). Jedyne źródło jest tak pełne lakun, że doprawdy trudno nań oprzeć przekonywające wnioski. Por., w rekonstrukcji Kniepa, G. 1,137a: [inter eam vero] quae [cum extraneo, et eam, quae cum viro suo coemptionem fecerit, hoc interest, quod illa quidam] cogere coem[pti]onatorem [potest], ut [se re]m[ancip]et, cui ipsa velit [haec autem virum suum] nihil[o] magis potest cogere, quam et filia patrem. Sed filia quidam nullo modo patrem potest cogere, etiamsi adoptiva est; haec autem < virum > repudio misso proinde conpellere potest, atque si ei numquam nupta fuisset. Autorzy zazwyczaj postulują procedurę extra ordinem w tym przypadku, być może analogiczną do tej stosowanej od czasów leges Iulia et Pappia do zmuszenia pater familias do wyrażenia zgody na małżeństwo dziecka pod władzą.

${ }^{50}$ A jak wiemy, przedmiot mancypacji, jeśli jest rzeczą ruchomą: zwierzęta, niewolnicy i osoby wolne, musi być obecny podczas rytuału: G. 1,121: In eo solo praed [i]orum mancipatio a ceterorum mancipatione differt, quod personae serviles et liberae, item animalia quae mancipi sunt, nisi in praesentia sint, mancipari non possunt. 
klasycznych należały do rzadkości. Naprawdę trudno sobie wyobrazić, by August wprowadził normę specjalnie regulującą to zanikające w jego czasach zjawisko! ${ }^{51}$

Znacznie bardziej przekonują pomysły tych autorów, którzy w intepretacji D. 24,2,9 idą za tematyką monografii, z której zaczerpnięto tekst. I tak Solazzi ${ }^{52}$ uważał, że procedura rozwodowa miała zapewnić rzeczywistość rozwodu dokonanego po odkryciu cudzołóstwa żony. Miałaby zatem na celu wykluczenie pozorowania rozwodu po cudzołóstwie żony; takie divortium simulatum miałoby uchroić męża przed accusatio lenocinii. Dla Solazziego procedura rozwodowa zupełnie nie miała znaczenia dla ważności rozwodu: zostosowanie jej ułatwiało jedynie stwierdzenie, czy dano zadość postanowienim lex Iulia de adulteriis.

Tym samym tropem poszedł Edoardo Volterra ${ }^{53}$. Lex Iulia rzeczywiście wprowadziła procedurę rozwodową polegającą na udziale siedmiu świadków w akcie, który wynikał z realizacji nakazu ustawy rozwiedzenia się z cudzołożną żoną pod groźbą popełnienia zbrodni stręczycielstwa. Tak jak Solazzi, i Volterra uważał, że obecność świadków gwarantowała, iż rozwód rzeczywiście się odbył - wykluczała pozorowane zerwanie dokonane w celu obejścia ustawy. Mąż zyskiwał też pewny dowód pozwalający odrzucić oskarżenie o stręczycielstwo.

${ }^{51}$ A zatem możemy odrzucić proponowaną przez Levy'ego następująca, niezwykle głęboką i zupełnie nieuzasadnioną - rekonstrukcję tekstu: <uxorem coemptione in manum receptam neque remancipatam maritus ex lege non dimittit $>$ nisi septem civibus Romanis puberibus adhibitis praeter libertum eius, qui divortium faciet (por. E. Levy, op. cit., s. 46; P. Jörs, W. KunKel, L. Wenger, op. cit., s. 282 i przyp. 11.). Szerzej na ten temat w przygotowanym studium Remancipatio a rozwód. Contra tezie Levy’ego, a zwłaszcza jej implikacjom interpolacjonistycznym por. też P. E. CorbetT, op. cit., s. 239; E. Volterra, m.in. w Per la storia, cit. s. 409-410, 413 [=228-230, 213]. Podobnie również O. RobledA, El matrimonio, cit., s. 261-263, choć oczywiście w innym zakresie niż Volterra. Por. także R. Astolfi, op. cit., s 317-318.

${ }^{52}$ S. SolazzI, Studi sul divorzio: 3. Il divorzio senza forme, [w:] Scritti di diritto romano, III, (1925-1937), Napoli 1960, s. 33-39, zwł. 34-35 i przyp. 4 [= «BIDR» 34 (1925), s. 295-319]; por. Też G. LonGO, op. cit., s. 89-90.

${ }^{53}$ Summa jego poglądów: E. Volterra, Il matrimonio, cit. s. 302. 
Świadectwo siedmiu świadków umożliwiało również precyzyjnie określić chwilę dokonania rozwodu - co w przypadku lex Iulia de adulteriis miało niebagatelne znaczenie: od tego momentu zaczynał biec okres 60 dni, w których jedynie były mąż mógł oskarżyć kobietę o zbrodnię cudzołóstwa, po nich oskarżenie przysługiwało już wszystkim, stając się accusatio popularis.

Roztropne poglądy Solazziego i Volterry zostały przejęte przez większą część doktryny ${ }^{54}$, choć całkiem niedawno - o czym pisałem powyżej - odrzucił je zupełnie Riccardo Astolfi. Autor ten powrócił do argumentów zwolenników powszechnego obowiązywania normy D. 24,2,9 opartych na trzech tekstach jurystów klasycznych, w których dopatrywano się śladów stosowania przewidzianej przez D. 24,2,9 procedury. Dwa z analizowanych poniżej źródeł z D. 24,2,9 łączy explicité scholion 1 do Bas. 60,37,44 (wersja grecka D. 48,5,44/43/).

VIII. Procedura Rozwodowa poza D. 24,2,9?

VIII.1. D. $24,1,35$

D. 24,1,35 (Ulp. 34 ad ed.): Si non secundum legitimam observationem divortium factum sit, donationes post tale divortium nullius momenti sunt, cum non videatur solutum matrimonium.

W tytule poświęconym darowiznom między małżonkami czytamy, że jeśli rozwód poczyniono bez względu na zalecenie ustawowe, darowizny poczynione między małżonkami będą nieważne, bo małżeństwo nie uległo rozwiązaniu.

${ }^{54}$ Por. też M. Kaser, Das römische Privatrecht ${ }^{2}$, I, München 1971, s. 325-326. 
Rzeczywiście źródło - bez względu na rozumienie terminu legitima observatio ${ }^{55}$, nastręcza ogromych trudności ${ }^{56}$. Żadna z formułowanych dotychczas hipotez nie wydaje się być satysfakcjonująca.

$\mathrm{Na}$ pewno należy odrzucić bardzo interpolacjonistyczne podejście Ernsta Levy'ego. Autor ten rozwijając swój pomysł, że D. 24,2,9 dotyczyło małżeństw cum manu, w sposób zdecydowanie przesadzony ,zrekonstruował" myśl Ulpiana. Zauważmy przede wszystkim, że źródło nie mogło dotyczyć problemu darowizn w małżeństwie, w którym kobieta była podporządkowana mężowi: wszak w takim związku żona nie ma majątku, a zatem w ogóle nie ma tu możliwości podarowania czegokolwiek przez nią lub jej ${ }^{57}$.

Edoardo Volterra starał się zrazu zneutralizować problem, dowodząc, że porównianie z innymi źródłami (a zwłaszcza z D. 24,1,64) jednoznocznie wskazuje na manipulacje justyniańskie w analizowanym tekście. Ponad dekadę później uznał natomiast, że wyrażenie Ulpiana należy rozumieć jako potwierdzenie, że małżeństwo ulega rozwiązaniu wtedy, gdy ustaje wola pozostawania w małżeństwie, co oznaczałoby w konkretnym przypadku, że gdy małżeństwo trwa mimo adulterium, darowizny naturalnie będą nieważne. Tylko czy możemy spodziewać

${ }^{55}$ Przy czym rozumienie samego pojęcia „legitima observatio" rodzi problemy; E. Levy, op. cit., s. 24 thumaczył je właśnie tak („,nach der gesetzlichen Vorschrift”), uznając przy tym samo słowo «observatio» za piętno Tryboniana. I choć rzeczywiście zbitka pojawia się w Corpus Iuris tylko w tym źródle, odnajdujemy ją również w innym tekście należącym do corpus ulpiańskiego: Ulp. 23,10. Analiza tego źródła, poświęconemu testamentom żołnierzy, które są ważne mimo, że sporządzone sine legitima observatione pozwala zauważyć, że dla jurysty legitima observatio ma funkcję synonimiczną do regula iuris.

${ }^{56}$ „La maggior difficoltà”: E. VolTerra, Per la storia, cit., s. 415-416 [= s. 235236]; w Il matrimonio, cit., s. 304-305, autor ten zmitygował swoją pierwotną hipotezę interpolacjonistyczną, przychylając się raczej do klasyczności tekstu w zasadniczej części.

${ }^{57}$ Por. E. Levy, op. cit., s. 23-25, 48. Rekonstrukcja proponowana przez Levy'ego: Si nuntio non misso uxor ex lege Iulia de adulteriis de manu dimissa sit, donationes inter virum et uxorem factae nullius momenti sunt, cum non videatur solutum matrimonium. 
się, że Ulpian „wygaśnięcie woli małżonków“ chciał nazwać "legitima observatio"?

Wedle Francesco de Martino tekst należy czytać w ścisłym związku z hipotezą na temat stosowalności normy D. 24,2,9 w przypadku adulterium $^{58}$. Rozwód cudzołożnicy dokonany z uchybieniem procedurze byłby nieskuteczny, czyli małżeństwo w świetle ustawy trwałoby dalej, uniemożliwiając darowizny między partnerami. Czy jednak można sobie wyobrazić taki przypadek praktyczny, w którym mogłaby znaleźć zastosowanie przekazana przez Ulpiana idea? Mało prawdopodobne, by po rozwodzie z powodu cudzołóstwa któreś z małżonków chciało jeszcze obdarowywać drugie!

Wypada również odrzucić supozycję Solazziego ${ }^{59}$, że sensu tekstu należy upatrywać w zaleceniu, by małżonkowie przeprowadzali swój rozwód z całym ustawowym ceremoniałem, by uniknąć wątpliwości co do swojego status i - co za tym idzie - ważności poczynionych już po rozstaniu darowizn. Jakże bowiem uzgodnić ją z przekazem D. 24,1,64? Jak już mieliśmy okazję zauważyć, źródło to właśnie zajmuje się wątpliwościami powstałymi na skutek braku formalnych przesłanek rozwodowych.

Może zatem - choć przyznaje, że jest to pomysł zbudowany na podstawach prawie równie wątlych, jak przedstawione przed chwilą poglądy - należałoby nadać zwrotowi legitima observatio znaczenie inne niż „norma ustawowa“. Jeśli uznamy, że jest to termin równoznaczny z iuris regula (por. przyp. 56 oraz Ulp. 23,10$)^{60}$, być może wolno nam jest rozumieć pierwsze zdanie źródła w następujący sposób: ,jeśli rozwód uczyniono bez zachowania ogólnych zasad prawa"? Te ogólne zasady to w przypadku rozwodu przekonanie, że ustanie af-

${ }^{58} \mathrm{~F}$. De Martino, Chiesa e stato di fronte al divorzio nell'età romana [w:] Festschrift für Werner Flume zum 70. Geburtstag, Köln 1978, s. 148.

${ }^{59}$ S. Solazzi, Il divorzio senza forme, cit., s. 38.

${ }^{60}$ Milites quomodocumque fecerint testamenta, valent, id est etiam sine legitima observatione. Nam principalibus constitutionibus permissum est illis, quomodocumque vellent, quomodocumque possent, testari. Idque testamentum, quod miles contra iuris regulam fecit, ita demum valet, si vel in castris mortuus sit, vel post missionem intra annum. 
fectio maritalis musi być trwałym stanem ducha (iudicium animi, por. D. 24,2,3). Rozwód zatem dokonany niezgodnie z tą norma, to sytuacja, w której partnerów nie charakteryzuje chęć wytrwania w decyzji o zerwaniu związku. Taka hipoteza zdaje się być podbudowana kontekstem palingentycznym naszego źrodła ${ }^{61}$. Lenel połączył D. 24,1,35 z D. $23,3,40$ i D. $24,2,5^{62}$. Pierwsze z tych źródeł omawia sytuację łudząco przypominającą nasze pierwsze teksty: kobieta rozwiódłszy się, powraca do męża. Powstaje pytanie, czy posag dany przy pierwszym małżeństwie, a nieodebrany po rozwodzie, może być traktowany jako posag w drugim małżeństwie ${ }^{63}$. Możemy sobie wyobrazić, że oryginalny problem rozwiązywany przez Ulpiana mógł być jeszcze wzbogacony o element nierzeczywistego rozwodu. W drugim tekście rozważa się problem wywołanego przez córkę na szkodę ojca rozwodu (dzięki niemu jej mąż mógłby zatrzymać posag ${ }^{64}$. I znów: wydaje się, że zerwanie wywołane przez kobietę $\mathrm{w}$ celu wzbogacenia partnera kosztem dawcy posagu może nosić znamiona pozorowanego rozwodu.

${ }^{61}$ Por. R. Astolfi, op. cit., s. 319-320. Autor ten jednak uważa, założywszy powszechny obowiązek stosowania procedury rozwodowej, że legitima observatio to przepis lex Iulia ustanawiający wymóg siedmiu świadków dla każdego rozwodu.

${ }^{62}$ Palingenesia, cit., II, col. 647.

${ }^{63}$ D. 23,3,40 (Ulp. 34 ad ed.): Divus Severus rescripsit Pontio Lucriano in haec verba: «Si mulier, quae dotem dederat, post divortium rursus in matrimonium redit non revocatis instrumentis, non dubitabit is, apud quem res agetur, secundum voluntatem mulieris, quae utique non indotata redire in matrimonium voluit, partibus suis fungi quasi renovata dote».

${ }^{64}$ D. 24,2,5 (Ulp. 34 ad ed.): Si filia emancipata idcirco diverterat, ut maritum lucro dotis adficiat, patrem fraudet, qui profecticiam dotem potuit petere, si constante matrimonio decessisset, ideo patri succurrendum est, ne dotem perdat: non enim minus patri quam marito succurrere praetorem oportet. Danda igitur est ei dotis exactio, atque si constante matrimonio decessisset filia. 
VIII.2. D. 38,11,1 ORAZ SANKCJE ZA UCHYBIENIE LEX IULIA

Kolejnym źródłem, które w interpretacji niektórych autorów zdaje się potwierdzać powszechne obowiązywanie D. 24,2,9, jest D. 38,11,1:

D. 38,11,1 pr.-1 (Ulp. 47 aded.): Ut bonorum possessio petipossit unde vir et uxor, iustum esse matrimonium oportet. Ceterum si iniustum fuerit matrimonium nequaquam bonorum possessio peti poterit, quemadmodum nec ex testamento adiri hereditas vel secundum tabulas peti bonorum possessio potest: nihil enim capi propter iniustum matrimonium potest. [1] Ut autem haec bonorum possessio locum habeat, uxorem esse oportet mortis tempore. Sed si divortium quidem secutum sit, verum tamen iure durat matrimonium, haec successio locum non habet. Hoc autem in huiusmodi speciebus procedit. Liberta ab invito patrono divortit: lex Iulia de maritandis ordinibus retinet istam in matrimonio, dum eam prohibere talii nubere invito patrono. Item Iulia de adulteriis, nisi certo modo divortium factum sit, pro infecto habet ${ }^{65}$.

Jurysta wyjaśnia, że bonorum possessio na podstawie Edyktu przyznaje się mężowi i żonie, tylko w przypadku iustum matrimonium. Jest zatem jasne - rozumuje dalej Ulpian - że matrimonium iniustum nie daje podstaw do wprowadzenia w majątek spadkowy na podstawie Edyktu, tak jak i nie nie daje możliwości objęcia spadku czy to na podstawie testamentu pretorskiego czy cywilnego ${ }^{66}$. Z kolei w $§ 1$ Ulpian

${ }^{65}$ E. LeVY, op. cit., s. 21-23; 47-48 konsekwetnie zmienia tekst tak, by stosował się do małżeństw połączonych z conventio in manu mariti: itaque cessat edictum, si liberta sb invito patrono divorterit: nam etsi lege Iulia de maritandis oridinibus alii nubere invito patrono prohibetur, tamen matrimonium solvitur. Item mulier, quae coëmptione in manum convenit, divortio facto bonorum possesionem petere non potest, quamvis non ex lege Iulia de adulteriis dimissa sit.

${ }^{66}$ To porównanie można, jak sądzę, wyjaśnić na dwa różne sposoby: 1) ustawy małżeńskie Augusta wyłączały zdolność spadkobrania osób stanu wolnego, za takich byli uważani partnerzy żyjący w związku niezgodnym z prawem, czyli mimo pozorów małżeństwa, 
wyjaśnia, że bonorum possesio (unde vir et uxor) ma miejsce tylko jeśli kobieta jest (prawną) małżonką w momencie śmierci męża. Od tej konstantacji przechodzimy do problemu prawnego: a co wtedy, jeśli po rozwodzie małżeństwo trwa ,iure “? Odpowiedź jest jednoznaczna: bonorum possessio nie będzie miała miejsca, choć związek trwa wobec prawa. W ostatniej, najbardziej dla nas interesującej części źródła, Ulpian egzemplifikuje, kiedy małżeństwo trwa iure, mimo że ustała affectio, mimo że strony dokonały rozwodu. Dzieje się tak, gdy

1. wyzwolenica rozwodzi się z mężem-patronem bez jego zgody;

2. gdy małżonek repudiuje cudzołożną żonę, uchybiając procedurze przewidzianej przez lex Iulia de adulteriis.

Trwanie małżeństwa iure oznacza, że nie wywołuje ono pozytywnych skutków prawnych - albo raczej, jak błyskotliwie ujął to Volterra, że przepisy ustaw Augusta czynią rozwód nieskutecznym jedynie w zakresie własnego obowiązywania ${ }^{67}$.

rzeczywiście go nie zawarli, nic im się zatem, jako caelibes nie należało z testamentów. 2) Drugą możlwość sugeruje lektura komentarza scholiasty do wersji greckiej D. 38,11,1 (schol. 1 ad Bas. 45,5,1), który poleca zapoznać się z D. 34,9,2,2 oraz z 24,1,13 (co mocno dziwi, tekst ten nie dotyczy zupełnie problemu rozwodu: myślę, że mamy do czynienia z błędem kopisty i rzeczywista referencja odsyłała do D. 34,9,13, być może należałoby poprawić zatem $\kappa \delta$ ' $\tau \imath$. $\theta$ ' u Heimbacha, VI 543 oraz u Scheletmy i Holwerdy, B VII 2724 nº 2 - na $\left.\lambda \delta^{\prime} \tau \imath \tau . \theta^{\prime} ?\right)$. Oba te źródła - jeśli moja poprawka jest wiarygodna - pokazuja, że prawo rzymskie przewidywało jako sankcje za małżeństwo niezgodne z prawem brak możliwości dziedziczenia po partnerze, nawet na podstawie jego testamentu. I tak źródło D. 34,9,2,2 wraz z poprzedzającym je D. 34,9,2,1, wzięte z Instytucji Marciana, przypominają o reskrypcie Sewera i Antonina, zakazującym urzednikowi prowincjonalnemu, który ożenił się z przedstawicielką lokalnej społeczności wbrew mandatowi, dziedziczenia po niej, także w przypadku, gdyby kobieta ustanowiła go dziedzicem. Podobna zasada stosowana była przy sprzeczym z senatusconsultum małżeństwie tutora z pupilką. $§ 2$ mówi o tym, że zasady tej nie stosowano symetrycznie: bezprawnie poślubiona mieszkanka prowincji i pupilka mogły dziedziczyć po swym mniemanym mężu, jeśli je ustanowił spadkobierczyniami w testamencie. Z kolei w D. 34,9,13 Papinian zdecydował, że spadek po kobiecie, która poślubiła współsprawcę w cudzołóstwie, a następnie ustanowiła go dziedzicem, powinien przypaść fiskusowi, a nie wdowcowi. Takie małżeństwo było bowiem niezgodne z prawem (por. D. 23,2,26).

${ }^{67}$ E. Volterra, Il matrimonio, cit., s. 302. Por. też z nieco innym rozłożeniem akcentów R. Astolfi, op. cit., s. 321-322. 
Widzimy zatem, że repudium cudzołożnej dokonanane niezgodnie z D. 24,2,9 jest jak najbardziej skuteczne. Kobieta traci status żony w sensie wszystkich płynących z tego przywilejów. Dla pełnego obra$\mathrm{zu}$ sytuacji po dokonanym rozwodzie wbrew lex Iulia de aduleriis brakuje informacji, co dzieje się z urodzonymi już po nim dziećmi cudzołożnicy. Można mniemać, że nie miałyby ono statusu dzieci małżeńskich, ale niestety żadne źródło nie rozważa tego problemu.

\section{VIII.3. Komentarz Gaiusa do Ustawy XII Tablic.}

Trzecie budzące wątpliwości źródło to fragment komentarza Gaiusa do Ustawy XII Tablic, umieszczony jednak przez kompilatorów justyniańskich w tytule o adulterium. Tekst ten, jak podkreślił Levy, już od czasów komentatorów bizantyjskich zawsze łączono z treścią D. 24,2,968.

D. 48,5,44 (43) (Gai. 3 ad l. XII tab.): si ex lege repudium missum non sit et idcirco mulier adhuc nupta esse videatur, tamen si quis eam uxorem duxerit, adulter non erit. Idque Salvius Iulianus respondit, quia adulterium, inquit, sine dolo malo non committitur: quamquam dicendum, ne is, qui sciret eam ex lege repudiatam non esse, dolo malo committat.

Gaius rozważał zapewne następujący kazus: podejrzana o adulterium kobieta, rozwiedziona bez zachowania procedury, poślubiła innego mężczyznę. Powstał problem, czy jej drugi mąż popełnił cudzołóstwo, nieświadomie łącząc się z partnerką, której poprzednie małżeństwo trwało. Przywołane przez Gaiusa zdanie Juliana wyklucza taką możliwość, gdyż zbrodni nie można popełnić bez złego zamiaru.

Jak każde źródło związane z naturą rzymskiego małżeństwa, i to było przedmiotem gorących debat. Już sam jego kontekst budzi kontrowersje: bo którą lex ma na myśli jurysta? Bohaterkę swojej monografii, to jest Ustawe XII Tablic, czy też lex Iulia de adulteriis, na co wzkazywać mogłaby kolokacja tekstu w Digestach ${ }^{69}$ ? Wydaje się uprawnio-

${ }^{68}$ E. Levy, op. cit., s. 18-19. Por. sch. 1 do Bas. 60,37,44

${ }^{69}$ Zwolennikiem pierwszego poglądu był R. YAron, 'Minutiae', cit. s. 3-7; po- 
ne rozwiązanie zaproponowane przez Astolfiego ${ }^{70}$ : być może Gaius, posługując się znacznie lepiej znanym stanem prawnym wynikającym z lex Iulia, tłumaczył niejasną procedurę rozwodową w prawie archaicznym. Takie pośrednie stanowisko pozwala nam bez dalszych zastrzeżeń uwzględnić komentarz do Ustawy XII Tablic w rozważaniach nad naturą normy D. 24,2,9.

Omawiane źródło, wedle Bonfantego, ma być dowodem na istnienie wymógu formalnej procedury rozwodowej, przynajmniej w przypadkach rozwodu jednostronnego ${ }^{71}$. Autor ten zresztą wyrzuca jako interpolowane wtrącenie et idcirco mulier adhuc nupta esse videatur, podobnie zresztą jak i iure tamen durat matrimonium z D. 38,11,1,1 i cum non videatur solutum matrimonium (D. 24,1,35) ${ }^{72}$ oraz ostatnie zdanie tekstu ${ }^{73}$. Jak już dowodziłem powyżej, taki pogląd wydaje się zbyt daleko posunięty.

Z kolei Volterra ${ }^{74}$ uznał źródło za raczej klasyczne. Romanista postulował, że kobieta była uważana za żonę pierwszego męża do chwili, gdy nie zawarła drugiego małżeństwa. W tej chwili pierwszy związek ustawał. „Pozostawanie poślubioną” ma wedle Volterry znaczenie takie, iż pierwszy mąż nie może oskarżyć żony o adulterium: accusatio iure mariti było możliwe dopiero po dokonanym wedle przepisu D. 24,2,9 rozwodzie. Także ostatnia fraza podejrzewana o interpolacje przez sporą

dobnie E. Levy, op. cit., s. 18-21 oraz przyp. 6 na s. 19. Drugi w zasadzie został przyjęty przez pozostałą część doktryny, por. zwłaszcza argumenty E. VolterRa, Intorno a D. 48.5.44 (43), cit., s. 5-6, który podniósł, że kazus przedstawiany w tekście nie mógł w ogóle być przedmiotem rozważań przed lex Iulia, bo adulterium nie stanowiło ówcześnie crimen ściganego publicznie.

${ }^{70}$ R. Astolfi, op. cit., s. 322-323.

${ }^{71}$ P. Bonfante, op. cit., s. 338-339 i przyp. 1 i 1.

${ }^{72}$ Podobnie C. Longo, Diritto di famiglia, 1934, s. 383; G. Longo, op. cit., s. 94. Contra R. Astolfi, op. cit., s. 323 i przyp. 56.

${ }^{73}$ Podnosi się, że fraza ta wydaje się kontrastować z tym, co Gaius powtarza za Julianem. Por. też R. Astolfi, op. cit., s. 328-329, który doszukiwał się w tym niedobrym gramatycznie zdaniu glosy poklasycznej.

${ }^{74}$ E. Volterra, Il matrimonio, (cit. n. 4) 304-307, patrz też, Tenże, Introno a D. 48.5.44(43), [w:] Studi Biondi, II, Milano 1956, s. 3-18 [= Scritti giuridici II, Napoli 1991, s. 521-536]. 
część doktryny, jest odczytywana przez Volterrę w sensie potwierdzającym poprzednią część źródła ${ }^{75}$ : nie da się zarzucić dolus, czyli elementu konstytuującego adulterium, nie tylko temu, kto nie wiedział, że kobieta nie została należycie rozwiedziona, ale także temu, kto o tym wiedział. Nie popada zatem pod sankcje przewidziane za adulterium taki mężczyzna, który poślubił źle-rozwiedzioną kobietę; wszak nowe małżeństwo rozwiązało dawne, nawet niezgodny z lex Iulia rozwód wywoływał skutki w ius civile. Trzeźwo zauważa Volterra, że gdyby zdanie to było naprawdę interpolowane, należałoby się w nim spodziewać odniesienia do dopuszczalnych w czasach justyniańskich powodów jednostronnego rozwodu. Podsumowując: nie wydaje się, by D. 48,5,44 (43) mogło poświadczać o powszechnym stosowaniu normy z D. 24,2,976, a jedynie jej aplikacje do rozwodów wymuszonych przez lex Iulia de adulteriis.

\section{PODSUMOWANIE: NIEFORMALOŚĆ ROZWODÓW A WOLNOŚĆ MAŁŻEŃSKA}

Mam nadzieję, że udało mi się potwierdzić nieformalność rozwodu w rzymskim prawie klasycznym. Forma wprowadzona przez D. 24,2,9 - której zresztą nie łączyłbym z przekazem Swetoniusza - miała znaczenie - jak uważał Volterra -jedynie przy rozwodzie wywołanym sankcją za stręczycielstwo wprowadzona przez lex Iulia de adulteriis coercendis. Przekonują o tym liczne źródła wskazujące na zerwanie małżeństwa

${ }^{75}$ E. Volterra, Introno a D. 48.5.44(43), cit., s. 13-14 [= 531-533].

${ }^{76}$ Gwoli kompletności musimy wspomieć także o pomyśle C. Venturiniego, Divorzio informale e 'crimen adulterii' (per una riconsiderazione di D. 48.5.44[43]), «Seminarios Complutenses de derecho romano» 4 (1992), s. 133-156, który uznał, skonfrontowawszy D. 24,1,35,38,1,11 pr.-1 oraz D. 48,5,44(43) z seriąźródeł nakładających ograniczenia na wyzwolenia niewolników w przypadku adulterium, że przepis D. 24,29 miał charakter generalny, zaś źródło D. 48,5,44(43) odczytywano dotychczas błędnie jako wyłącznie dotyczące mężczyzn. Zdaniem Venturiniego natomiast, przypadek opisany przez Gaiusa mógłby zaczynać się od rozwodu dokonanego przez kobietę. Norma D. 24,2,9 miała na celu uniknięcie obiektywnych wattpliwości co do rzeczywistości dokonanego rozwodu, repudium wobec 7 świadków byłoby zatem aktem wywołującym divortium (por. s. 147). Trudno podjąć dyskusję z tym poglądem, gdyż Venturini w ogóle nie zajął się interpretacją źródeł przemawiających za nieformalnością rozwodu, które omówiłem na początku artykułu. 
samym tylko faktem oraz formułowane przez jurystów wskazówki pozwalające uściślić, czy do rozwodu rzeczywiście doszło (zwrot posagu, nowe małżeństwo $\mathrm{z}$ inną osoba, wytoczenie skarg niedopuszczalnych między małżonkami). Z trzech źródeł powoływanych zazwyczaj jako dowód na powszechne stosowanie formy rozwodu w obecności świadków, dwa dają się doskonale połączyć tylko z Ustawq o cudzołóstwach (D. 38,11,1 raz D. 48,5,44 (43)). Trzecie, D. 24,1,35 pozwala na taką interpretację, która nadaje wyrażeniu legitima observatio znaczenie nie ściśle związane z konkretną normą prawa, ale z ogólnymi zasadami prawa dotyczącymi małżeństw: to jest, że wygasają one, gdy trwale zniknie affectio maritalis. Co więcej, źródła te, zwłaszcza w związku z D. 24,2,11,2 dobitnie pokazuja, że niedochowanie przepisu ustawy, wcale nie powoduje nieskuteczności rozwodu: małżeństwo iure civili zostało rozwiązane, a sankcją za uchybienie normie jest jedynie brak możliwości wyciagania pozytywnych dla siebie konsekwencji z faktu bycia lub nie - w świetle Ustaw Augusta - nadal w małżeństwie: wyzwolenica zatem nie może zawrzeć nowego małżeństwa, małżonkom nie przysługuje bonorum possessio wedle IV klasy Edyktu, darowizny między nimi nie będą skuteczne, a mąż niepoprawnie rozwiedzionej cudzołożnicy zapewne nie może oskażyć jej iure mariti o adulterium.

$* * *$

O czym mówią nam nasze źródła o nieformalności rozwodu? Bez wątpienia potwierdzają utrwaloną w doktrynie tezę o wolności małżeństw w prawie rzymskim. Fritz Schulz z pewnością miał rację, upatrując powodów wprowadzenia tej niezwykle niepraktycznej koncepcji małżeństwa, $\mathrm{w}$ dążeniu do równouprawnienia kobiety, jako równorzędnego podmiotu związku małżeńskiego ${ }^{77}$. Niepraktyczność tej konstrukcji - wszak na zewnątrz trudno było stwierdzić, czy dwoje ludzi było małżonkami czy nie, jeśli stan ten zależał wyłącznie od wewnętrzej woli każdego z nich z osobna - łagodziło forowane przez jurysprudencję klasyczną domniemanie istnienia małżeństwa. Wyraźnie zauważamy je w źródle:

${ }^{77}$ Por. F. Schulz, The Classical Roman Law, Oxford 1951, s. 103, oraz cały rozdział III „Husband and Wife”; TenżE, The Principles of Roman Law, Oxford 1934, rozdział „Humanity”, s. 189-222. 
D. 23,2,24 (Mod. 1 regul.): In liberae mulieris consuetudine non concubinatus, sed nuptiae intellegendae sunt, si non corpore quaestum fecerit.

Pożycie z wolną kobietą - o ile nie jest prostytutką - uważa się za małżeństwo, nie konkubinat. Teza taka współgra doskonale $\mathrm{z}$ przekazem Paulusa (D. 24,2,3) mówiącym o tym, że iudicium animi wywołujące rozwód musi być trwałe, a zatem, że zakładamy istnienie affectio maritalis między małżonkami, dopóki nie udowodnimy czegoś przeciwnego.

Na zakończenie wypada powrócić do problemu umieszczenia fragmentu D. 24,2,9 w ogólnym wszak tytule de divortiis et repudiis. Wydaje mi się uzasadnione postulowanie możliwej duplex interpretatio tego tekstu. Umieszczenie przez kompilatorów fragmentu z komentarza o ustawie o cudzołóstwach w przepisach dotyczących wszystkich rozwodów antycypuje justynańskie ostateczne ograniczenie rozwodów: całkowity zakaz rozwodów dwustronnych (Nov. 117,10) oraz ścisłe ograniczenie do bardzo poważanych powodów rozwodów jednostronnych (C. 5,17,11-12, potem Nov. 117,7-9 [542]). Zapewne dla Komisji Kodyfikacyjnej procedura, wprowadzona przez Augusta na potrzeby lex Iulia de adulteriis, wydała się stosowna dla każdego rozwodu - miała je uczynić trudniejszymi, co zresztą współgra ze wspomnianym we wstępie obowiązkiem sporządzanie listu rozwodowego w NTh. 12). Problemem pozostaje jedynie praktyczny brak przypadków z praktyki prawnej mogących potwierdzić prawdziwość tej tezy i skuteczność normy. Siedmiu świadków asystujących rozwodowi mamy właściwie tylko w bardzo dziwacznym P. Ness. III 57. Trudno jednak z dokumentu sporządzonego w Nessanie już w czasach arabskich wyciągać przekonywające wnioski ${ }^{78}$.

${ }^{78}$ Por. Na ten temat mój: A Priestly Divorce in the Seventh Century Palestine: Various Legal Orders at Work (the Case of P. Nessana III 57, a. 689), [w:] Marriage: Ideal - Law - Practice. Proceedings of a Conference held in Memory of Henryk Kupiszewski, ed.: Z. SŁużEWsKa, J. URBAnIK, Warsaw 2005, s. 199-218. 
The Formality of Divorce under the Classical Roman LAW: D. 24.2.9 AND Augustean DIVORTIIS MODUM IMPONERE

\section{Summary}

The present article critically reexamines the classical sources on divorce. The key text, D. 24,2,9, Paul's commentary on Julian Law on Adulteries is confronted with the fragments in which the jurisprudence addressed the troublesome issue of establishing the moment of real divorce (D. 24,1,64; 25,2,11 pr.; 23,2,33 \& Frag.Vat. 106-107). The traditional scholarship (P. Bonfante, G. Longo, S. Solazzi, E. Volterra, O. Robleda, J. Huber) is evaluated, with a particularly critical approach to the most recent studies of R. Astolfi. In the second part, the sources, prima facie, deposing in favour of the general application the divorce procedure in D. 24,2,9, are taken into consideration (D. 24,1,35; 38,1,11 and D. 48,5,44/43/). A new interpretation is presented in regards to the vexed problem of legitima observatio in D. 24,1,35. Finally, a duplex interpretatio is postulated for the seven-witness procedure found at D. 24,2,9. This hypothesis seems to provide for the better understanding of the text collocation in the general title de divortiis of the Digest. 